\title{
Revitalizing the Interior of Ndalem Puspowijoto as a Laweyan Batik Shop and Museum in Surakarta.
}

\author{
Yosafat Adi Pradipta a,1, ${ }^{,}$, Raden Ersnathan Budi Prasetyo b,2 \\ ${ }^{a}$ Interior Design Study Program, the Faculty of Visual Arts and Design, the Indonesian Institute of the Arts (ISI) Surakarta. \\ ${ }^{b}$ Interior Design Study Program, the Faculty of Visual Arts and Design, the Indonesian Institute of the Arts (ISI) Surakarta. \\ 1 yosafatadi29@gmail.com*; ${ }^{2}$ ernest.prasetyo@gmail.com; ${ }^{3}$ \\ * Corresponding Author
}

Received 25 February 2015; accepted 8 May 2015; published 13 May 2015

\begin{abstract}
Revitalizing the Interior of Ndalem Puspowijoto as a Batik Shop and Museum in Laweyan Surakarta is an effort to preserve cultural heritage buildings. The revitalization aims to maintain the building and as a means of education about batik and local wisdom of Laweyan village for the visitors and general public who care about batik. The design process is carried out using Kurtz programming including the orientation stage, the base program stage, interative programming, and design as feedback. The design approach uses the Art Deco style with the theme of Parang Saudagar. The results of the revitalization are in the form of the museum that can be used for educational purposes, and Laweyan Batik shop which has a place that is comfortable, safe, and able to accommodate the needs of both managers and visitors. The facilities consist of a lobby, café, deposit counter, shop, ticketing room, digital audio education, main display, fabric display, item display, maintenance room, multipurpose room, pantry, toilet, office, and prayer room.
\end{abstract}

\section{KEYWORDS}

Revitalization,

Interior,

Shop,

Museum,

Art Deco

This is an openaccess article under the CC-BY-SA license

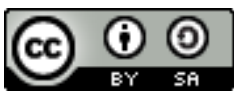

\section{Introduction}

The city of Surakarta or better known as Solo is a city that has a history of various cultures in it, more than 250 years since the city was founded on February 17, 1745 (Kusumastuti 2017). From the journey this city has been through which is more than 250 years old, Surakarta has a historic old building site that ages more than 50 years old or can be called a cultural heritage site (Lokaprasidha 2017). Surakarta's cultural heritage buildings are regulated in the Decree of the Mayor of Surakarta No.646 / 1-2 / 1/2013 concerning Amendments to the Decree of the Mayor of Surakarta Level II Number 646/116/1/1997 concerning the Designation of Ancient Historic Buildings and Areas in the Municipality The Surakarta Level II region which is protected by Law Number 5 of 1992 concerning Cultural Heritage has stipulated 69 cultural heritage buildings located in the city of Surakarta (Rudiatmo 2013).

History noted, Laweyan was originally known as a farmers' village which became the center of lawe trade (lawe refers to yarn as the raw material for cloth) which was the raw material for cotton at that time. These materials came from Pedan, Juwiring, and Gawok which belonged to the Pajang Kingdom area (Mlayadipuro 1984)

Laweyan's success is based on a shift of local livelihoods from farmers to batik craftsmen. Rivers, as the natural potential, support the development of farmers' villages into batik villages, especially for the stamped batik. The batik stamp tools also support the development of the village to become the village of stamped batik industry until it 
reaches success (Ratnawati and Susena 2017). This is indicated by the existence of high fenced houses, gates, Indische-style inside buildings and houses with Art Deco architecture (Krisnina Maharani Tandjung 2002).

Symmetry ornaments with the Art Deco style were widely applied in the houses of Laweyan batik merchants in the early 20th century, while still applying the Javanese symbol ornaments (Krisnina Maharani Tandjung 2002). The house of Puspowijoto family is located in Sayangan Kulon No.9 Laweyan, Surakarta. It is characterized by a building with an Indische style architecture with a Javanese spatial layout pattern on a land area of more than $1200 \mathrm{~m}$.

The Central Statistics Agency (BPS) of Surakarta City explained that visitors to the tourism objects of Surakarta City have increased by $0.8 \%$ each year. The development of tourism in the city of Surakarta is influenced by the Laweyan area as one of the tourism objects in Surakarta. Alpha Febela Priyatmono as the Head of FPKBL (Forum Pengembangan Kampoeng Batik Laweyan) or the Forum of Laweyan Batik Kampong Development, strengthens the statement of BPS Surakarta that the development of Laweyan tourism is based on the a special site providing education about Laweyan and as a place selling souvenirs to the society, for both domestic and foreign visitors also the next generation in Laweyan. Such place can provide the Batik Shop and Museum under one roof.

Markovic explained that the highest expectations of the visitors are the expectations of freedom of access, facilities, appearance and exhibition, also communication and information for visitors. This is in line with Alpha Febela Priyatmono's hope, to have a freedom of access, which can provide space for the press and domestic/government media to contribute in introducing Laweyan batik products and museum as tourism spots in the city of Surakarta (Mangedaby, Setioko, and Sari 2017).

Based on the explanation above, it can be concluded that the revitalization of Ndalem Puspowijoto as a Laweyan batik shop and museum is indeed necessary so that domestic and foreign visitors not only come to buy products but also want to learn about batik with their families or groups.

Museums have a fairly complex functions and space requirements. A museum is an institution, a place for storing, maintaining, securing and utilizing artifacts as physical evidences of human culture as well as the nature and its environment to support efforts to protect and preserve the nation's cultural wealth (Hamzah and Utomo 2016). Museums have various types, one of which is a local museum. Sutaarga added that a local museum is a museum in which the collection consists of a collection of objects originating, representing and relating to material evidence of humans and/or their environment from the regency or municipality where the museum is located (Salayanti 2018).

The museum requires several needs/facilities to support the activities in it. The requirements for the needs/facilities of a museum building, quoting Muhammad Sulthon, consist of: main entrance, service entrance, permanent exhibition hall, temporary exhibition hall, ticket box, goods storage, supporting buildings (toilets, multipurpose room, canteen, and lobby), office, storage, and maintenance room (Sulthon 2016).

The revitalization of Ndalem Puspowijoto as Laweyan Batik shop and museum lifts up the character of the Surakarta batik element design as the theme. One of the batik motifs with potential and character is Parang Saudagar Batik. Parang Saudagaran Batik has a meaning adapted from Batik Parang Barong, that is self-control in the dynamics of 
continuous business, wisdom in movement, and caution in acts. Parang saudagaran batik was adapted from the spirit of the Laweyan people.

The interior design style in the revitalization of Ndalem Puspowijoto is Art Deco. Art Deco style is a modern decorative architectural and interior design style. The Art Deco style is a design movement originating from Paris in 1920s, which is ornamental, glamorous, and elegant, with the use of materials such as exotic woods, aluminum, stainless steel, and inlay wood (Gumulya 2020). The application of color psychology to the revitalization of Ndalem Puspowijoto uses art deco color tones elements with the parang saudagaran motif.

\section{Method.}

The location used for the revitalization of Laweyan Batik Shop and Museum in Surakarta is at Ndalem Puspowijoto. The interior revitalization of Ndalem Puspowijoto as Laweyan batik shop and museum applies the Kurtz programming method as the stages in the design process. There are four main stages in the Kurtz programming method. First, the Orientation Stage: the stage of assessing the philosophy, activities and goals the client wants to achieve based on consultation with the client. Second, the Basic Program Development stage: is the stage of assessing client needs, reviewing alternative support and initial program plans. Third, Interative Programming: is the stage of presenting the basic program to clients. Fourth Design (Design as Feedback): the process undertaken is to develop a schematic design that is carried out after the last iteration process of the programming.

The design approach implements a theme approach, a stylistic approach, a functional approach, and an aesthetic approach. The theme of the revitalization process is Parang Saudagaran batik motif. The stylistic approach with Art Deco style is an architectural and interior design style which tends to be modern decorative in character. The functional approach in interior design is to design a space by considering the use of space and users' needs following the criteria of furniture grouping, space dimensions, activities space, social distance, visual and acoustic privacy, and flexibility and adaptability (Ching 1996). The color approach is one of the important aesthetic elements in interior design because color can create aesthetics.

\section{Results and Discussion}

Ndalem Puspowijoto is one of the houses of laweyan merchants that triumphed in the past, and today the authenticity of the building is still being maintained. This place has a deep historical background and an authentic architectural design in Indische style. The revitalization of Ndalem Puspowijoto building uses the concept of adaptation, which is expected to be able to provide benefits in accordance with the current developments. Ndalem Puspowijoto will be revitalized into a building with new functions, as a batik store and museum, which are attractive, safe, and comfortable by maintaining historical values and the principles of preserving cultural heritage values.

The revitalization of Ndalem Puspowijoto will make limited changes to maintain the authenticity of the cultural heritage buildings. The revitalization with the concept of adaptation follows the rules in accordance with Law of the Republic of Indonesia No. 11 of 2010 concerning cultural heritage, article 80, paragraph (1) and (2) which contains the revitalization of cultural heritage, and must still pay attention to the spatial layout, layout positioning, and functions with rearranging its functions following cultural values. 
Ndalem Puspowijoto, which is revitalized into a shop and museum, has different functions and space requirements. According to the Regulation of the Minister of Trade of the Republic of Indonesia Number: 53 / M-Dag / Per / 12/2008 concerning Guidelines for the Arrangement and Development of Traditional Markets, Shopping Centers, and Modern Stores, Stores are buildings with business functions used to sell goods and consist of only one seller (Anonim, n.d.).

Kotler describes several types of shops, such as specialty shops, convenience stores, grocery stores, supermarkets, and so on (Kotler 2003). Based on Kotler's description, the type of Ndalem Puspowijoto store is a specialty store that sells various items of batik, such as fabrics, clothes, shirts or dresses. Special shops provide facilities/needs for both visitors and managers. The arrangement and appearance of the display are important to support the comfort of the room users (Sumarno and Indarto 2016). Astrid Kusumowidagdo noted tha, store needs / facilities consist of selling space (area for display), merchandise space (area for storing stock items), personnel space (a special area for employees), and customer space (areas for visitors, such as lobbies, fitting rooms, and deposit counter) (Astrid Kusumowidagdo 2005).

Art deco walls are often made of smooth stucco and have rounded corners and use new materials such as stained glass, neon, chrome, mirrors, and frosted glass panels. The application of color psychology to the revitalization of Ndalem Puspowijoto uses art deco color slices with the motif of the parang saudagaran batik. In the revitalization of Ndalem Puspowijoto, it uses an Art Deco color approach and the color of Parang Saudagaran batik motif. The following is the theory of Art Deco color according to the book Designer's Guide to Color 3 which can be a design reference to present an art deco impression on the revitalization of ndalem Puspowijoto (Jeanne Allen 1986).

Traditional batik has a distinctive color, when is viewed from a nuance perspective, it can be categorized as dark or gloomy. Traditional batik colors directly or indirectly have symbolic meanings. Colors directly have symbolic meanings according to supernatural powers. The color of batik has an indirect meaning associated with its symbolic meaning.

The relationship between spaces in the interior revitalization of Ndalem Puspowijoto as Laweyan batik shop and museum uses a linear inter spaces relationship pattern. This pattern is a row of several spaces, each of which is connected to another room with an elongated feature. Each room is directly related. Spaces have different shapes and sizes, but have important functions to be positioned in the same row of spaces (Suptandar 1982).

Zoning and Grouping of spaces in the revitalization of Ndalem Puspowijoto are categorized into four different types of areas, namely: public areas, semi-public areas, private areas, and service areas. Circulation is a guide that assists a trip or site plan taking place in a space or area. Circulation provides continuity for visitors to the functions of space, one of them is by using signs in the space as directions for separate ways (Suptandar 1982).

The circulation system used in the revitalization of Ndalem Puspowijoto's interior as a batik shop and museum in Laweyan Surakarta is a linear circulation system, because this system has a clear central area and circulation direction, making it easier for visitors, guests, and managers to enter the space they want with various pathways. It can be curved, or consist of segments, cut across other routes, branch off, and forming loops. 


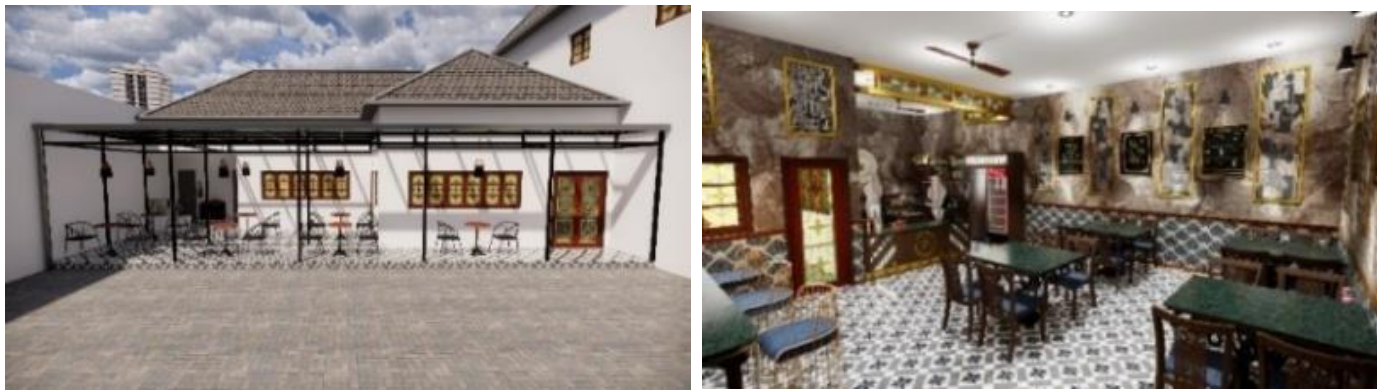

Fig. 1.Outdoor Café and Indoor Café Area.

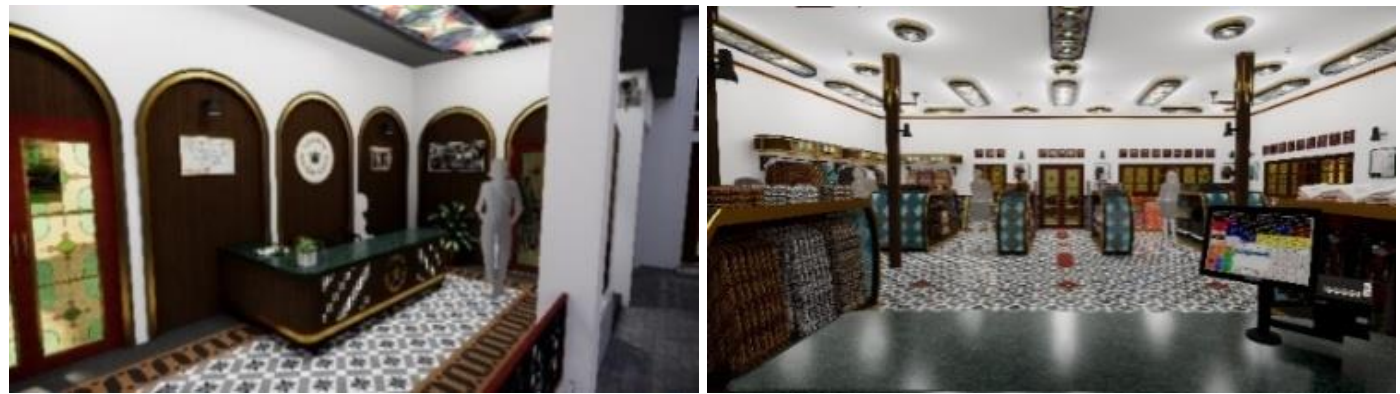

Fig. 2. Lobby dan Shop Area.
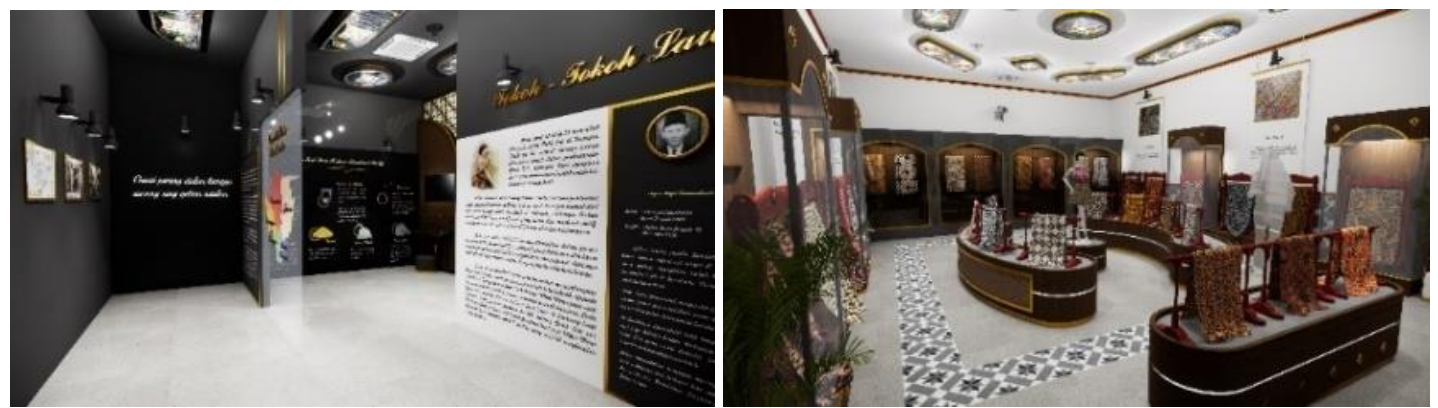

Fig. 3. Audio Visual Education \& Main Display Area.
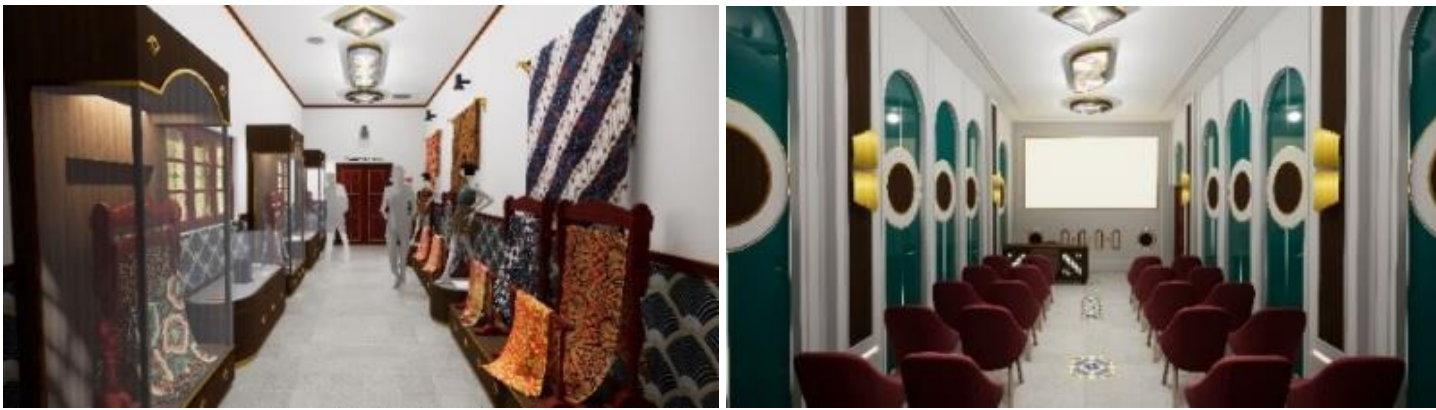

Fig. 4. Item Display \& Multipurpose Room.

\section{Conclusion}

Revitalizing the Interior of Ndalem Puspowijoto as Laweyan Batik Shop and Museum in Surakarta is an effort to preserve cultural heritage buildings as a place for education about Laweyan to the public, visitors and the next generation of Laweyan kampong. The interior revitalization of Ndalem Puspowijoto is presented in an Art Deco style with the theme of Parang Saudagar batik pattern.

The interior revitalization of Ndalem Puspowijoto is expected to become a center providing services or facilities based on the needs of existing managers or visitors, in order to produce educational and business development outputs related to Batik. This revitalization is designed by using the basic reference of ergonomic design based on the literature studied, so that the visitors or managers feel safe and comfortable in carrying out their activities. 


\section{References}

Anonim. n.d. Peraturan Menteri Perdagangan Republik. Indonesia Tentang Pedoman Penataan Dan Pembinaan Pasar Tradisional, Pusat Perbelanjaan Dan Toko Modern.

Astrid Kusumowidagdo. 2005. "PERAN PENTING PERANCANGAN INTERIOR PADA STORE BASED RETAIL.” Dimensi Interior 3 (1).

Ching, Francis DK. 1996. Ilustrasi Desain Interior. Jakarta: Erlangga.

Gumulya, Devanny. 2020. "DESAIN PRODUK DENGAN INSPIRASI ART DECO EROPA ERA TAHUN 1920 DENGAN PENDEKATAN CHART MORFOLOGI.” Jurnal Patra 2 (2). https://doi.org/10.35886/patra.v2i2.114.

Hamzah, Faizal, and Eko Tri Utomo. 2016. "Sapta Pesona Pada Museum Mandala Wangsit Siliwangi Kota ImplementasiBandung." Jurnal Pariwisata III (2).

Jeanne Allen. 1986. Designer's Guide to Color 3. San Francisco: Chronicle Books.

Kotler, Philip. 2003. Marketing Insights from A to Z : 80 Concepts Every Manager Needs to Know. New Jersey: John Wiley \& Sons, Inc.

Krisnina Maharani Tandjung. 2002. Rumah Solo, Rumab-Rumah Klasik Paduan Kultur Jawa Eropa. Singapore: Times Media Private Editions.

Kusumastuti, Kusumastuti. 2017. "PROSES DAN BENTUK 'MEWUJUDNYA' KOTA SOLO BERDASARKAN TEORI CITY SHAPED SPIRO KOSTOF.” Region: Jurnal Pembangunan Wilayah Dan Perencanaan Partisipatif7 (1). https://doi.org/10.20961/region.v7i1.5782.

Lokaprasidha, Pramesi. 2017. "The History of Batik and The Development of Kampung Batik Kauman as a Local to International Tourism Destination." Journal of Tourism and Creativity 1 (1).

Mangedaby, Eva Artmey, Bambang Setioko, and Suzanna Ratih Sari. 2017. "Pengaruh Desa Wisata Kampoeng Batik Laweyan Terhadap Fungsi Permukiman Di Kelurahan Laweyan Kota Surakarta." Teknik 38 (1). https://doi.org/10.14710/teknik.v38i1.12057.

Mlayadipuro. 1984. Sejarah Kyai Ageng AnisKyai Ageng Laweyan, Urip - Urip. Surakarta: Museum Radya Pustaka.

Ratnawati, Anista Yulia, and Edy Susena. 2017. "Analisis Manajemen Pemasaran Batik Di Kampoeng Batik Laweyan Surakarta.” Jurnal INFORMA Politeknik Indonusa Surakarta 3.

Rudiatmo, FX. HAdi. 2013. Benda Cagar Budaya (BCB). Surakarta.

Salayanti, Santi. 2018. “ANALISA POLA BUDAYA SUNDA PRIMODIAL (Pola Tiga) PADA TATA RUANG DAN BENDA PAJANG DI MUSEUM NEGERI JAWA BARAT SRI BADUGA BANDUNG." Idealog: Ide Dan Dialog Desain Indonesia 2 (1). https://doi.org/10.25124/idealog.v2i1.1176.

Sulthon, Muhammad. 2016. "Redesain Museum Purbakala Patiayam Kudus. Laporan Tugas Akhir." Semarang.

Sumarno, and Indarto. 2016. "Implementasi Prinsip Quadrow Helix Dalam Rancang Bangun Show Room Di Sentra Industri Kerajinan Rotan Sukoharjo.” Surakarta.

Suptandar, J.Pamudji. 1982. Perancangan Tata Ruang Dalam (Interior Design). Jakarta: Penerbit PT Djambatan. 